\title{
COMMENTARY
}

\section{Refugees, Migration, and Gated Nations: The Eritrean Experience}

\author{
Dan Connell
}

Said Ibrahim, aged twenty-one, orphaned and blind, was making a living as a singer in Adi Quala bars when a member of Eritrea's national security force claimed that one of his songs had "political" content and detained him at the notorious Adi Abieto prison (interview, Adi Harush Camp, Ethiopia, May 30, 2012). After a month Said was released, but he was stripped of his disability payments for two years when he refused to identity the lyricist. "I went back to my village and reflected about it," he told me over tea at an open-air café in the Adi Harush refugee camp in Ethiopia four years ago. "If the system could do this to a blind orphan, something was very wrong." After appealing to his neighbors for help, two boys, aged ten and eleven, sneaked him into Ethiopia and all three asked for asylum.

Tigiste Beyene, aged thirty-five, was pregnant with her second child when she was sent to a desert prison in northern Eritrea for attending a banned Pentecostal prayer meeting (interview, Mai Aini Camp, Ethiopia, May 28, 2012). Upon release, she was given ten months to renounce her faith and pressed to do so by the local Eritrean Orthodox priest, who had turned her in in the first place, and by her family, who had to guarantee the state EN50,000 to get her out (U.S.\$3,300 at the official exchange rate). Four months later, she paid a smuggler EN30,000 to take her to Ethiopia. "The dark side of my life was not the year in prison, but the time I spent at home with my family," she said as she sat on the dirt floor of her cramped mud-brick house. "It was a torment I could not bear."

African Studies Review, Volume 59, Number 3 (December 2016), pp. 217-225

Dan Connell is a visiting researcher at Boston University's African Studies Center. He has written numerous books and articles on Eritrea and currently is writing a book on the refugee crisis. E-mail: danconnell@mac.com 
The newcomers joined more than sixty-five thousand Eritreans housed in five camps along the tense border with Ethiopia that year, a border whose disputed location was the spark that set off a fierce fight between the two countries a decade earlier and remains both a source of potential conflict and Eritrea's rationale for keeping the younger generation in the army indefinitely today. It is also the reason the government gives for prohibiting nearly every organization or activity it doesn't directly control, from political parties and NGOs to private prayer meetings and protest singers.

Today their small northeast African country, about the size of Pennsylvania with a population of about four million, is one of the largest per capita producers of asylum seekers in the world (UNHCR 2015a). Many languish in desert camps. Some have been kidnapped, tortured, and ransomed-or killed-in the Sinai (Connell 2013a; Van Reisen 2012, 2013). Others have been left to die in the Sahara or drowned in the Mediterranean. Eritreans in South Africa have been brutally attacked in paroxysms of xenophobic violence; some in Israel have been firebombed or beaten by ultranationalists. Some trying to reach the United States and Canada have been refused entry under post-9/11 "terrorism bars" based on past association with an armed movement-the very one they are now fleeing.

When I returned to the camps in Ethiopia in March 2016 for the fourth time in as many years, the number of Eritrean refugees in the country had swollen to nearly 155,000, according to the U.N. Refugee Agency (UNHCR), though so many had moved on to other destinations - or died trying-that these statistics didn't begin to reflect the magnitude of the exodus (ReliefWeb2016). By this time, many I had met in 2012 were no longer there, gone instead to Libya to try to reach Europe. A growing number of the newest arrivals were just kids. A whole generation appeared to be on the move.

Over the course of these four years, I've traveled to nineteen countries on five continents to dig deeper into who the refugees are, why they fled, how they got out, and what they experienced on their journeys, interviewing more than five hundred in lengthy private sessions that I recorded and transcribed. ${ }^{1}$ A remarkable number manage to survive and carve out new lives, but some scrape by in low-wage jobs and others live off handouts from family members, while many thousands are stuck in limbo, lacking legal status and unable to marshal the resources or the stamina to keep moving. Among the worst off are those marooned in Djibouti's remote desert refugee camps, which for many is a cul-de-sac with no way out. And there are the thirty thousand stuck in Israel, where they are classified as "infiltrators," not refugees, and are under pressure to either self-deport or face detention, a devil's choice made all the more difficult by the expectations of safety and solidarity they'd had when they arrived (Connell 2013b).

The most horrifying of their misfortunes-the kidnapping, torture, and ransoming in the Sinai-has generated attention in the media and among human rights organizations, as have several tragic shipwrecks in the Mediterranean that claimed five hundred lives or more at a time. 
But the public response, like that to natural disasters, tends to be ephemeral, turning the refugees into objects of pity or charity with little grasp of who they are, why they take such risks, or what can be done to halt the hemorrhaging. This is abetted by the Eritrea government, which masks the political origins of these flows by insisting they are "migrants," not refugees, and no different from those of other poor countries like their neighbor and archenemy, Ethiopia. It is a fiction that's convenient for destination countries struggling with rising ultranationalist movements and eager for a rationale for turning the Eritreans (and others) away.

\section{Why They Flee}

Eritrea has been the scene of conquest, conflict, resistance, and repression for more than a century-colonized by Italy in the $1890 \mathrm{~s}$, occupied Britain in the 1940s, and then annexed by Ethiopia in the 1950s, against which it fought a thirty-year war for independence. That struggle pitted Eritreans against successive U.S.- and Soviet-backed regimes even as the nationalist movement fractured into warring factions until one army, the Eritrean People's Liberation Front, came out on top and defeated the Ethiopians. Statehood and internal recognition came after a U.N.-monitored referendum in 1993, but within five years the new nation had fought with all its neighbors, including most recently Ethiopia. A 1998-2000 border war claimed more than one hundred thousand lives on both sides before a truce was reached, but the basic dispute remains unresolved. An international commission rendered a decision in 2002 that both sides had agreed would be "final and binding," but Ethiopia has declined to implement it without further negotiations and Eritrea refuses to talk. This has left them in a state of "no-peace-no-war."

Betrayals, intrigue, and isolation throughout these years have scarred the Eritreans' outlook on the wider world and hardened their determination to go-it-alone. They have also nurtured a political culture of obsessive secrecy, absolute control, and intolerance of dissent. The victorious Eritrean People's Liberation Front was run by the super secret Eritrean People's Revolutionary Party that few front members even knew existed until its dissolution was announced after independence. That insular culture, together with a chip-on-the-shoulder mistrust of outsiders and a knee-jerk resort to force to resolve disputes, defines the postindependence state.

Eritrea is dominated by a single strong personality, the former EPLF commander and now president, Isaias Afwerki. He is surrounded by weak institutions with no viable successor, though there are persistent rumors of a committee-in-waiting due to his failing health. A constitution ratified in 1997 has never been implemented and no national elections have been held (Habte-Selassie 2003). Meanwhile, the three branches of government-nominally headed by a cabinet, a National Assembly, and a High Court-provide a façade of institutional governance, but power is exercised through informal networks that shift and change at the 
president's discretion. There is no organizational chart; nor is there a published national budget. Every important decision is made in secret. The ruling People's Front for Democracy and Justice, a retooled version of the liberation army, functions as a mechanism for mobilizing and controlling the population. No other parties are permitted. Nor are nongovernmental organizations that are not under state or party control. There are no independent trade unions, media, women's organizations, student unions, charities, cultural associations-nothing. All but four religious denominations have been banned, and those that are permitted have had their leaderships compromised (Connell 2011; Kibreab 2010; Tronvoll \& Mekonnen 2014).

Refugees I spoke with cite this lack of freedom-and fear of arrest should they question it - as one of the main reasons for their flight. But the camps in Ethiopia and Sudan reflect a highly unusual demographic: Most such populations comprise women, children, and elderly men, but UNHCR officials in Ethiopia and Sudan, the initial destinations for most who flee, say that among those registering in the camps there, close to half in recent years have been women and men under the age of twenty-five. The common denominator is their refusal to accept an undefined, open-ended national service, instituted on a limited basis in the 1990s but extended indefinitely after the border war. This, more than any other single factor, is propelling the exodus (HRW 2009; Kibreab 2016).

A few could be called purely "economic migrants," but the overwhelming majority are not seeking so much as fleeing, pushed by circumstances at home more than pulled by prospects elsewhere. This is a crucial distinction, since whether or not a person qualifies for political asylum under international law depends on the reason he or she left-whether there was a legitimate fear of persecution. The desire, say, to go to school or work to send money home or better one's life in some other way is not relevant. All refugees and migrants want this.

At its core, the refugee crisis reflects a fundamentally flawed experiment in nation-building; if left to run its course with no adjustments, it could result in a failed state. It is not only conscripted soldiers, teachers, farm laborers, and construction workers who leave. Nearly every time the national football team competes abroad, half the players refuse to come back. ${ }^{2}$ The young man who carried the flag for Eritrea at the London Olympics in 2012 refused to go home afterward. The nucleus of the refugee population in South Africa is made up of people sent there to study in the early 2000s who refused to go back. Dozens sent abroad for conferences do not return. Nor do many officials posted to embassies when they're recalled. They say they love their country-but they hate their state and those who rule it. Or fear them so much that they cannot live under their thumbs a day longer.

\section{Reception at the First Stop}

Many find that after risking their lives to get away, their first stop in either Sudan, Ethiopia, or Djibouti is little better. UNHCR has registered nearly 
four hundred thousand Eritrean refugees over the past decade, and many more have passed through the border states without being counted (Siegfried 2014). The agency's representative in Sudan told me he thought 70-80 percent of those who crossed into Sudan didn't register and didn't stay (interview, Khartoum, June 23, 2013). If he's right, a conservative estimate would put the total well above a half-million, probably 15 percent of the population. One reason so many move on is fear of kidnapping by human traffickers from within the refugee camps or, more recently, capture and forced repatriation to Eritrea by security forces operating there (Van Riesen et al. 2012, 2013).

Security in the Sudan camps has improved since a low point in 2012-13, when dozens of refugees were taken by force and sold to traffickers in the Sinai. But despite an increase in police posts, kidnappings continue to occur just outside the camps when people tend garden plots or go for firewood or water and at entry points in the border region. Few victims are accounted for, since most are not registered. Most of the people I interviewed in 2013 and 2015 also mentioned the limited facilities and opportunities in the camps, such as schools, training programs, and income-generating activities as factors encouraging them to leave as soon as they could.

This situation has produced the anomaly of a high rate of incoming refugees but stable or declining camp populations, as recent arrivals go to Libya as soon as they marshal the resources. UNHCR officials say the focus of refugee programming needs to shift to the city of Khartoum, even as strengthening security in eastern Sudan remains a high priority. The main obstacle is Sudanese government resistance to having more refugees in the urban areas.

Meanwhile, refugees pour into Ethiopia at alarming rates, particularly unaccompanied minors. UNHCR counted 107,000 refugees in the country at the start of 2015. By mid-2016 that had risen by 50 percent (UNHCR 2016c). The largest number come from Eritrea's central highlands and enter Ethiopia from there; once registered they are assigned to one of four camps in the Tigray region. The reasons most give for leaving, particularly those between the ages of seventeen and twenty-five, are the endless national service; the extent of regime control over their lives; the limited options for school or work; the extremes of punishment and public humiliation for real or imagined infractions; and the torture and abuse in the jails and prisons. Most unaccompanied minors I interviewed in March 2016 had little grasp of the political issues or risks; at that point they made up slightly more than half the new arrivals at the Enda Baguna Reception Center (232 of 459, including 186 boys and 46 girls). The total refugee population in the Tigray region at the end of May 2016 was 110,751, according to Ethiopia's Administration of Refugee and Returnee Affairs (ARRA). At least they are safe, unlike their counterparts in Sudan, but many find themselves languishing in the camps with no likelihood of improvement in their situation. There are international agencies operating here, and 
Ethiopia allows some to move to the cities if they demonstrate a means of support. Some even get scholarships to attend Ethiopian universities. But most are stuck; even if they get new skills, they are not allowed to work (Connell 2012).

Refugees from Muslim minorities are also fleeing in large numbers. Pastoralists from the western lowlands have been fleeing Eritrea since the 1960s during the early years of the independence war. Most went to Sudan and settled there. In recent years there has been an outflow from the southeast, an area populated by the Afar minority, an insular people whose traditional homeland is divided among Eritrea, Djibouti, and Ethiopia. Afar refugees share many reasons for flight with other Eritreans-indefinite national service, political repression, and economic dislocation-but most also cite discrimination and marginalization based on their ethnicity and culture. Since the crackdown on dissent and political and religious differences that followed the border war, many traditional Afar leaders and lower-level government administrators have fled the country after coming under suspicion of supporting the underground opposition. This left much of the local administration in the hands of Tigrinya speakers, which adds to the alienation (Connell 2015, 2016).

Many new arrivals describe conditions resembling colonial rule by foreigners who neither speak their language nor respect their culture. In their view they're being treated as an obstacle to development strategies hatched in faraway Asmara to serve the political and economic interests of the Tigrinya-dominated regime. This is reinforced by the use of Afar territory to house numerous military bases and prisons. Their outflow is further aggravated by an intensifying drought that threatens their pastoralist way of life even as regional conflict curtails access to safety valves.

I visited their camps twice in 2015. Many had traveled by foot through the Danakil Depression, where temperatures exceed $50^{\circ} \mathrm{C}$. Others had slipped across the heavily militarized frontier with Djibouti and made their way to Ethiopia from there. Some had escaped earlier in single-sail dhows to Yemen, settling along the coast or continuing to Saudi Arabia, the Gulf Arab states, or Turkey, but Yemen's civil war has blocked that route and created a reverse flow to Djibouti and Ethiopia. This puts additional pressure on overstretched host governments and communities in these countries. It also raises the specter of an avenue for Islamist extremism incubated in Yemen to jump the Bab al Mandab Straits.

UNHCR Ethiopia counted nearly 29,000 Afar refugees in Ethiopia's Afar Region at the start of 2015, most in two ARRA camps. But officials say that many more have crossed the border without registering to live among the local Afar community. Under these circumstances, it is likely that somewhere between a third and a half of all Eritrean Afars are now outside their country.

The main camp in Djibouti is at Ali Addeh in a desert valley near the Ethiopian border. Established in 1991 with seven thousand refugees, it has grown to more than fourteen thousand, which the Djibouti refugee 
authority (ONARS) considers full capacity. It is a cul-de-sac with almost no economic activity and few prospects for its residents except for the small number hired to teach in a church-funded primary school or the local clinic. Most are Somalis, but there are minorities of Eritreans and Ethiopians (roughly 700 and 350, respectively). A second camp was reopened in 2012, though few Eritreans were settled there. However, many now coming from Yemen are being assigned to it. A third has also been opened north of Djibouti City to accommodate refugees from Yemen, but many Eritrean Afars are dispersed among the large Afar community in the city. Those in the new camp get far more attention than those in Ali Addeh and are likely to get better services and options, which will stir resentment and frustration among those already in the country.

\section{What Can Be Done}

Refugee populations in all three states are chronically unstable, with many simply using these states as way stations for onward journeys rather than as destinations in themselves. The Ethiopian government's decision to allow a growing number of Eritreans to move about the country under its Out-of-Camp Program has made it a more welcoming destination overall than the other three and the safest and most secure destination for refugees today-also one of the easiest to leave (Samuel Hall Consulting 2014). ${ }^{3}$ More states need to follow this example and institute urban refugee programs.

Meanwhile, continuing refugee influxes threaten to overburden existing sanitation and water facilities as well as schools and shelter capacity and the limited livelihood support programs that are now functioning in all three border countries, so all services and facilities desperately need expansion. A stepped-up effort to meet basic needs, coupled with the visible presence of aid organizations and other manifestations of international concern, would generate hope and dampen the frustration and despair in this community and position refugees to return to Eritrea in event of reforms there. It could also strengthen the ability of donor countries to promote peace and reconciliation between Ethiopia and Eritrea and a slowing of the refugee exodus out of the region, which is the sine qua non for an end to this crisis.

Durable solutions start with an understanding of the refugees-who they are, why they flee, what they seek, and how they can be mobilized as agents of change rather than reduced to passive recipients of international charity. Slowing secondary migration from border states can be achieved by reducing security risks, improving conditions in the camps, expanding out-of-camp policies and urban support programs, and providing services appropriate to the particular populations and age sets. But major changes are needed in third countries with regard to reception, status, and protection. Urgent international action is also needed to halt the human trafficking, especially on the trans-Sahara routes. But in the end, stemming 
the outflow can only be achieved by fostering changes within Eritrea to discourage flight and draw refugees home.

What most refugees said they wanted before they would go back was, in this order, (1) an end to the extended program of national service; (2) release of prisoners and a transparent justice system with an end to torture and terror; (3) constitutional rule; (4) freedoms of speech and movement within the country and in and out of it; and (5) choices in schools and work. In regard to the latter demand, many young people balk at the almost total control over their lives, convinced that children of elites get choices over which school to attend, what career to pursue, what ministry to do national service in, and so on, that the rest do not.

Few expect anything to change under the present government, even if personalities and positions shift, a belief that rightly or wrongly reflects a profound loss of trust in their government. This needs to be addressed in specific, concrete ways if the goal is to slow the outflow, let alone encourage any who have left to return. But in the end, things need to change within Eritrea and between Eritrea and Ethiopia. Without a resolution of the border dispute, there can be no peace; without international engagement, there will be no resolution.

\section{References}

Connell, Dan. 1997. Against All Odds: A Chronicle of the Eritrean Revolution. Trenton, N.J.: Red Sea Press.

- 2005. Conversations with Eritrean Political Prisoners. Trenton, N.J.: Red Sea Press.

- 2011. "From Resistance to Governance: Eritrea's Trouble with Transition." Review of African Political Economy 38 (129): 419-33.

- 2012. "Escaping Eritrea: Why They Flee and What They Face." Middle East Report no. 264 (Fall).

—. 2013a. "The Rerouted Trafficking in Eritrean Refugees." Middle East Report no. 268 (Fall).

- 2013b. "Refugees, Ransoms and Revolt: An Update on Eritrea." Middle East Report no. 266 (Spring).

—. 2015a. "Eritrean Afars: The Refugees You Never Hear About." Middle East Report no. 276 (Fall).

- 2015b. "Eritrean Refugees' Trek Through the Americas." Middle East Report no. 275 (Summer).

- 2016. "Caught in the Crossfire of Climate and Politics: The Eritrean Afars in Ethiopia.” Middle East Report no. 277 (Winter).

Habte-Selassie, Bereket. 2003. The Making of the Eritrean Constitution: The Dialectic of Process and Substance. Trenton, N.J.: Red Sea Press.

Human Rights Watch. 2009. "Service for Life: State Repression and Indefinite Conscription in Eritrea." New York: HRW.

Iyob, Ruth. 1995. The Eritrean Struggle for Independence: Domination, Resistance, Nationalism: 1941-93. Cambridge, U.K.: Cambridge University Press.

Jacquin-Berdal, D., and M. Plaut, eds. 2005. Unfinished Business: Ethiopia and Eritrea at War. Trenton, N.J.: Red Sea Press. 
Kibreab, Gaim. 2008. Critical Reflections on the Eritrean War of Independence: Social Capital, Associational Life, Religion, Ethnicity and Sowing Seeds of Dictatorship. Trenton, N.J.: Red Sea Press.

- 2016. Servitude for "Our Common Good": The Indefinite Eritrean National Service and Youth Exodus. London: James Currey.

- 2010. Eritrea: A Dream Deferred. Oxford: James Currey.

Mengisteab, Kidane, and Okbazghi Yohannes. 2005. Anatomy of an African Tragedy: Political, Economic and Foreign Policy Crisis in Post-Independence Eritrea. Trenton, N.J.: Red Sea Press.

Negash, Tekeste, and Kjetil Tronvoll. 2000. Brothers at War: Making Sense of the Eritrean-Ethiopian War. Oxford: James Currey.

Reid, Richard, ed. 2009. Eritrea's External Relations: Understanding Its Regional Role and Foreign Policy. London: Chatham House.

ReliefWeb. 2016. "Refugees and Asylum-Seekers from Ethiopia.” March 31. http:// reliefweb.int.

Samuel Hall Consulting. 2014. "Living out of Camp: Alternative to Camp-Based Assistance for Eritrean Refugees in Ethiopia." Report commissioned by the Norwegian Refugee Council. http:/ / samuelhall.org.

Siegfried, Kristy. 2014. "Sudan and Egypt Implicated in Human Trafficking." IRIN, February. http://www.irinnews.org.

Tronvoll, Kjetil, and Daniel Mekonnen. 2014. The African Garrison State: Human Rights and Political Development in Eritrea. Suffolk, U.K.: James Currey.

United Nations High Commissioner for Human Rights (UNHCR). 2015a. "Refugees and Asylum Seekers 2015, by Country of Origin.” UNHCR Global Trends 2015. www.unhcr.org.

- 2015b. "Report of the Commission of Inquiry on Human Rights in Eritrea. New York: UNHCR.

—. 2016c. "Ethiopia." http://reporting.unhcr.org.

Van Reisen, Mirjam, Meron Estifanos, and Conny Rijken. 2012. "Human Trafficking in the Sinai: Refugees between Life and Death.” Brussels: European External Policy Advisors, Tilburg University.

- 2013. The Human Trafficking Cycle: Sinai and Beyond. Brussels: Wolf Publishers.

Welde Giorgis, Andebrhan. 2014. Eritrea at a Crossroads: A Narrative of Triumph, Betrayal and Hope. Houston, Tex.: Strategic Books.

Wrong, M. 2005. I Didn't Do It for You: How the World Betrayed a Small African Nation. New York: HarperCollins.

\section{Notes}

1. Longer versions of this article can be found at my website: danconnell.net/ articles or danconnell.net/blog.

2. Seven members of the national football team defected in Angola in 2006, twelve in Tanzania in 2007, twelve in Kenya in 2009, and seventeen in Uganda in 2012. In December 2013 the coach and ten team members defected in Kenya. In October 2015 ten were granted asylum in Botswana.

3. Ethiopia initiated an out-of-camp scheme in 2010, under which Eritrean refugees who demonstrate an independent means of support, typically a relative but potentially an NGO sponsor, are given special identity cards and permitted to live in the cities. 